\title{
ANALISIS COMMON SIZE DAN RASIO KEUANGAN PADA SUBSEKTOR WHOLESALE (DURABLE \& NON-DURABLE GOODS) YANG TERCATAT DI BEI
}

\author{
Nuru Riani ${ }^{1}$, Zulkarnain Zulkarnain ${ }^{2}$ \\ Program Studi Akuntansi, Institut Manajemen Wiyata Indonesia ${ }^{1,2}$ \\ Sukabumi, Indonesia \\ rianinuru@gmail.com ${ }^{1}$, zulkarnain@imwi.ac.id ${ }^{2}$
}

\begin{abstract}
The purpose of this research was to calculate and analyse the financial performance of the Wholesale Durable \& Non-Durable Goods Subsector that were listed on the Indonesia Stock Exchange for the period 2017 and 2018 by using the financial ratio and common size method. The financial ratio method used liquidity ratios $(C R, Q R$, and cash ratio.), solvency (DAR and DER), activity (total assets turnover and inventory turnover), and profitability (GPM, NPM, and ROE). This reseach used secondary data in the form of statement of financial position and income statements. The method used was descriptive quantitative. The conclusion of the calculation using the financial ratio method was the company has been classified as less good that the results were not suit with the industry standards. For the calculation used common size, indicated that assets and equity decreased, while liabilities increased.
\end{abstract}

Keyword: Common Size Analysis, Financial Ratio, Wholesale Subsector

\section{PENDAHULUAN}

Setiap perusahaan tentu menginginkan usaha yang dijalankannya berjalan dengan baik dan terus berkembang dari waktu ke waktu. Dengan didukung oleh kemampuan untuk merencanakan, memperoleh, dan memanfaatkan sumber daya yang dimiliki, perusahaan dapat memaksimalkan sumber daya tersebut untuk meningkatkan kinerjanya secara efektif dan efisien. Oleh sebab itu, perusahaan perlu untuk mengambil keputusan-keputusan atau langkah baru yang dapat mendatangkan keuntungan bagi perusahaan hingga tercapainya tujuan yang diharapkan.
Penilaian kinerja merupakan hal yang perlu dilakukan supaya dapat mengukur sejauhmana perkembangan perusahaan dalam mencapai tujuannya. Selanjutnya, berdasarkan penilaian tersebut perusahaan dapat menentukan kebijakan untuk meningkatkan kinerja pada periode selanjutnya. Informasi yang dapat dijadikan sebagai bahan pertimbangan salah satunya adalah laporan keuangan. Laporan keuangan merupakan suatu informasi yang dapat memberikan gambaran mengenai kondisi keuangan perusahaan (Fahmi, 2015).

Tujuan dari laporan keuangan yaitu untuk memberikan informasi mengenai 
posisi keuangan dan kinerja keuangan perusahaan yang dapat bermanfaat bagi para pengguna laporan dalam mempertimbangan keputusan ekonomi (Fahmi, 2015). Namun, terkadang masih banyak pengguna yang kurang memahami atas informasi yang disajikan di dalam laporan keuangan. Oleh karena itu, analisis laporan keuangan dibutuhkan untuk mempermudah para pengguna dalam memahami laporan keuangan.

Salah satu metode yang dapat digunakan untuk mengukur kinerja keuangan perusahaan adalah analisis rasio keuangan. Analisis rasio keuangan merupakan analisis yang dilakukan terhadap laporan keuangan perusahaan untuk mengetahui tingkat kesehatan, tingkat risiko, dan tingkat keuntungan yang diperoleh perusahaan (Hery, 2015). Analisis rasio keuangan dilakukan dengan cara membandingkan berbagai perkiraan pada laporan keuangan. Analisis ini dapat mengungkapkan hubungan antar komponen yang dibutuhkan sehingga dapat dipakai untuk mengevaluasi kondisi keuangan serta kinerja perusahaan.

Selain itu, dalam menilai kinerja perusahaan dapat dilakukan dengan berbagai metode lain seperti metode analisis common size. Analisis common size atau analisis persentase per komponen merupakan teknik analisis yang dilakukan untuk mengetahui proporsi masing-masing komponen aset terhadap total aset seluruhnya dan juga untuk mengetahui proporsi masing-masing komponen liabilitas dan ekuitas terhadap keseluruhan total liabilitas dan ekuitas (Jumingan, 2017).

Analisis rasio keuangan dan analisis common size ini kemudian sama-sama diperlukan untuk mengetahui gambaran kinerja keuangan perusahaan secara lebih jelas. Hasil dari analisis laporan keuangan dan analisis common size dapat membantu memberikan pertimbangan mengenai prediksi masa depan perusahaan berdasarkan intepretasi berbagai hubungan (Munawir, 2014).

Sektor perdagangan merupakan salah satu sektor yang berpengaruh terhadap perekonomian Indonesia. Persaingan dalam bidang ini semakin ketat seiring dengan pesatnya perkembangan perekonomian. Hal ini menuntut perusahaan untuk memanfaatkan setiap peluang dalam kegiatan operasionalnya. Salah satunya yaitu Subsektor Perdagangan Besar atau Wholesale (Durable \& NonDurable Goods). Subsektor tersebut bergerak di bidang jual beli dalam partai besar. Perusahaan dalam Subsektor ini melakukan transaksi jual beli ke pedagang lain seperti pengecer atau kepada pemakai industri dalam jumlah besar. 
Secara umum pada tahun 2019, sektor ini mengalami pertumbuhan yang positif seiring meningkatnya tingkat kesejahteraan masyarakat dan jumlah penduduk kelas menengah ke atas. Hal yang lain, aktivitas kampanye pilkada/pemilu juga meningkatkan permintaan barang untuk kebutuhan logistik. Secara keseluruhan, penjualan barang-barang di dalam negeri mengalami kenaikan (Olivia \& Tendi, 2019).

Berdasarkan pada yang telah diuraikan sebelumnya, peneliti tertarik untuk melakukan analisis laporan keuangan dengan menggunakan pendekatan analisis common size dan rasio keuangan pada Subsektor Wholesale yang terdaftar di Bursa Efek Indonesia dengan tujuan untuk mengetahui kinerja Subsektor tersebut pada tahun 2017 dan 2018 melalui laporan posisi keuangan dan laporan laba rugi.

Penelitian mengenai analisis rasio keuangan untuk memberikan gambaran mengenai kinerja pada perusahaan telah dilakukan oleh beberapa peneliti di antaranya Grisely et al. (2015), Purwantini (2017), dan Firdausia \& Ariyanto (2018). Namun, sampel yang digunakan oleh para peneliti sebelumnya adalah perusahaanperusahaan pada Subsektor Wholesale dan Retail Trade. Penelitian yang dilakukan pun hanya menggunakan rasio keuangan tanpa menggunakan analisis common size.

\section{METODE PENELITIAN}

Penelitian ini menggunakan pendekatan yang bersifat deskriptif kuantitatif yaitu dengan menguraikan hasil temuan yang didapatkan. Studi pustaka juga dilakukan melalui literatur seperti artikel jurnal, dan data lainnya yang dapat dijadikan sebagai referensi. Data yang digunakan adalah data sekunder berupa laporan keuangan perusahaan pada Subsektor Wholesale yang diunduh melalui situs Bursa Efek Indonesia (www.idx.co.id). Sampel yang dianalisis adalah laporan keuangan perusahaan Subsektor Wholesale yang telah dipublikasikan di BEI pada periode tahun 2018 dan 2017.

Data yang telah terkumpul akan dianalisis menggunakan teknik-teknik sebagai berikut:

\section{Analisis Common size}

Analisis common size yaitu analisis yang dilakukan dengan cara menghitung perbandingan elemen tertentu sebagai bagian dari elemen lain. Rumus yang digunakan yaitu:

Common size neraca

$$
=\frac{\text { Item dalam neraca }}{\text { Total aset }} \times 100 \%
$$

Common size laba rugi

$$
=\frac{\text { Item dalam laba rugi }}{\text { Penjualan }} \times 100 \%
$$




\section{Rasio Likuiditas}

Rasio likuiditas adalah rasio yang menggambarkan kemampuan perusahaan dalam melunasi liabilitas jangka pendeknya (Kasmir, 2017). Rasio likuiditas yang akan digunakan adalah current ratio, quick ratio, dan cash ratio.

Rasio lancar atau current ratio adalah rasio yang digunakan untuk mengukur kemampuan perusahaan dalam membayar liabilitas jangka pendeknya. Standar umum bagi perusahaan untuk berada di titik aman adalah jika hasil perhitungan rasio lancarnya minimal $200 \%$ atau 2 kali (Kasmir, 2017). Rasio lancar dihitung dengan menggunakan rumus:

$$
\text { Current Ratio }=\frac{\text { Aset lancar }}{\text { Utang lancar }} \times 100 \%
$$

Rasio cepat atau quick ratio adalah rasio yang digunakan untuk menggambarkan kemampuan perusahaan dalam melunasi liabilitas jangka pendek dengan aset lancar tanpa mengikutsertakan nilai persediaan. Standar umum rasio cepat pada industri yang menunjukkan kinerja baik bagi perusahaan adalah $150 \%$ atau 1,5 kali (Kasmir, 2017). Rumus yang digunakan:

$$
\begin{aligned}
\text { Quick Ratio }= & \frac{\text { Aset lancar }- \text { Persediaan }}{\text { Utang lancar }} \\
& \times 100 \%
\end{aligned}
$$

Rasio kas atau cash ratio adalah rasio yang digunakan untuk menghitung seberapa besar kemampuan kas yang tersedia di perusahaan untuk melunasi liabilitas jangka pendek. Ketersediaan uang kas dapat ditampakkan dari tersedianya kas atau setara kas yang tidak dibatasi penggunaannya. Perhitungan rasio ini memperlihatkan kemampuan perusahaan yang sesungguhnya dalam melunasi liabilitas jangka pendeknya. Standar industri untuk rasio kas adalah sebesar 50\% atau 0,5 kali (Kasmir, 2017). Rumus untuk menghitung rasio kas adalah sebagai berikut:

$$
\text { Cash Ratio }=\frac{\text { Kas }}{\text { Utang lancar }} \times 100 \%
$$

\section{Rasio Solvalibitas}

Rasio solvabilitas adalah rasio yang digunakan untuk menghitung seberapa besar aset perusahaan dibiayai dengan liabilitas (Kasmir, 2017). Jenis rasio solvabilitas yang akan digunakan dalam analisis ini adalah debt to asset ratio dan debt to equity ratio.

Debt to asset ratio adalah rasio utang yang digunakan untuk menghitung perbandingan jumlah liabilitas dengan jumlah aset. Rasio ini menunjukkan seberapa besar aset perusahaan dibiayai oleh liabilitas atau seberapa besar liabilitas berpengaruh pada aset perusahaan. Standar untuk rasio ini adalah sebesar $35 \%$ (Kasmir, 2017). Berikut ini rumus yang digunakan untuk menghitung debt to asset ratio: 
Debt to asset ratio $=\frac{\text { Total utang }}{\text { Total aset }} \times 100 \%$

Debt to equity ratio merupakan rasio untuk membandingkan liabilitas dan akuitas. Standar industri untuk rasio ini yaitu sebesar 90\% (Kasmir, 2017). Rumus untuk menghitung rasio ini adalah:

$$
\text { Debt to equity ratio }=\frac{\text { Total utang }}{\text { Total ekuitas }} \times 100 \%
$$

\section{Rasio Aktivitas}

Rasio aktivitas atau activity ratio adalah rasio yang digunakan untuk menghitung seberapa besar tingkat efisiensi perusahaan dalam memanfaatkan sumber daya pada kegiatan operasional sehari-hari (Kasmir, 2017). Jenis rasio aktivitas yang akan digunakan dalam analisis ini adalah total assets turnover dan inventory turnover.

Perputaran total aktiva (total assets turnover) adalah rasio yang digunakan untuk menghitung perputaran semua aset yang dimiliki perusahaan. Standar industri untuk rasio ini adalah 2 kali. Jika angka rasio kurang dari standar berarti perusahaan belum mampu memanfaatkan aset secara maksimal (Kasmir, 2017). Rumus untuk menghitungnya adalah sebagai berikut:

$$
\begin{gathered}
\text { Total assets turnover }=\frac{\text { Penjualan }}{\text { Total aset }} \times 1 \mathrm{kali} \\
\text { Perputaran persediaan (inventory }
\end{gathered}
$$
turnover) adalah rasio yang digunakan untuk menghitung jumlah perputaran dana yang diinvestasikan dalam persediaan pada satu periode. Standar umum industri untuk rasio ini sebanyak 20 kali. Perusahaan memiliki kinerja yang baik dan produktif jika hasil perhitungan rasio yang diperoleh tinggi. Jika rendah, itu artinya perusahaan memiliki kinerja yang kurang baik karena tidak bekerja secara produktif sehingga persediaan menumpuk (Kasmir, 2017). Rumus perputaran persediaan adalah:

$$
\text { Inventory turnover }=\frac{\text { Penjualan }}{\text { Persediaan }} \times 1 \text { kali }
$$

\section{Rasio Profitabilitas}

Rasio profitabilitas adalah rasio yang digunakan untuk mengukur kemampuan perusahaan dalam memperoleh keuntungan (Kasmir, 2017). Jenis rasio profitabilitas yang akan digunakan dalam analisis ini adalah gross profit margin, net profit margin, dan return of equity.

Margin laba kotor atau gross profit margin (GPM) adalah rasio untuk menilai tingkat laba kotor dibandingkan dengan penjualan. Standar industri untuk gross profit margin adalah 30\% (Kasmir, 2017). Rumus yang digunakan:

$$
\text { Gross profit margin }=\frac{\text { Laba kotor }}{\text { Penjualan }} \times 100 \%
$$

Margin laba bersih atau net profit margin (NPM) adalah rasio untuk menilai laba bersih setelah pajak dibandingkan dengan penjualan. Rasio ini menunjukkan pendapatan bersih perusahaan atas penjualan. Standar industri untuk rasio ini 
adalah 20\% (Kasmir, 2017). Rumus yang digunakan:

$$
\begin{aligned}
& \text { Net profit margin }=\frac{\text { Laba bersih }}{\text { Penjualan }} \times 100 \% \\
& \text { Return on equity (ROE) adalah }
\end{aligned}
$$
rasio untuk menilai kemampuan ekuitas untuk memperoleh laba. Standar industri untuk rasio ini adalah 40\% (Kasmir, 2017). Rumus yang digunakan:

Return on Equity (ROE)

$$
=\frac{\text { Laba Bersih }}{\text { Ekuitas }} \times 100 \%
$$

\section{HASIL DAN PEMBAHASAN}

\section{Gambaran Umum Perusahaan}

Perusahaan dalam Subsektor

Wholesale terdiri dari 33 perusahaan dan dapat dikelompokkan menjadi 4 (empat) ukuran yaitu small, medium, large, dan super yang dibedakan berdasarkan jumlah penjualan pada tahun 2018 dengan kriteria sebagai berikut:

Tabel 1 Ketentuan Ukuran

\section{Perusahaan}

\begin{tabular}{llccc}
\hline Ukuran & Kriteria & & \\
\hline Small & $\begin{array}{l}\text { Penjualan sampai dengan 300 } \\
\text { miliar rupiah }\end{array}$ & & \\
Medium & $\begin{array}{l}\text { Penjualan dari } \\
\text { sampai dengan }\end{array}$ & 1 & miliar \\
& $\begin{array}{l}\text { triliun } \\
\text { rupiah }\end{array}$ & & \\
Large & $\begin{array}{l}\text { Penjualan dari } \\
\text { sampai dengan }\end{array}$ & 10 & triliun \\
& $\begin{array}{l}\text { triliun } \\
\text { rupiah }\end{array}$ \\
Super & $\begin{array}{l}\text { Penjualan di atas } \\
\text { rupiah }\end{array}$ & triliun \\
\end{tabular}

Berdasarkan kriteria di atas, maka distribusi perusahaan pada Subsektor
Wholesale dapat digambarkan dalam tabel berikut ini:

Tabel 2 Distribusi Perusahaan

Subsektor Wholesale Berdasarkan

Ukuran

\begin{tabular}{lcc}
\hline Ukuran & $\begin{array}{c}\text { Jumlah } \\
\text { Perusahaan }\end{array}$ & $\begin{array}{c}\text { Total } \\
\text { Persen }\end{array}$ \\
\hline Small & 10 & $30 \%$ \\
Medium & 6 & $18 \%$ \\
Large & 10 & $30 \%$ \\
Super & 7 & $21 \%$ \\
Total & $\mathbf{3 3}$ & $\mathbf{1 0 0 \%}$ \\
\hline
\end{tabular}

Sumber: Data diolah (2020)

Data di atas menunjukkan terdapat masing-masing 10 perusahaan atau $30 \%$ dari 33 perusahaan yang termasuk dalam kategori small dan large. Terdapat 6 perusahaan atau $18 \%$ dari total perusahaan yang termasuk dalam kategori medium. Serta sebanyak 7 perusahaan atau $21 \%$ yang termasuk dalam kategori super yang berarti memiliki penjualan di atas 10 triliun rupiah pada tahun 2018. Subsektor Wholesale didominasi oleh perusahaan dengan penjualan kurang dari 300 miliar rupiah serta perusahaan dengan penjualan dari 1 triliun sampai dengan 10 triliun rupiah.

\section{Analisis Common Size Laporan Posisi}

\section{Keuangan}

Perusahaan menyajikan laporan posisi keuangannya pada akhir periode operasi. Laporan posisi keuangan mewakili 
aset, liabilitas, dan ekuitas perusahaan, serta hubungannya dengan satu sama lain. Laporan ini menganalisis laporan posisi keuangan dalam bentuk common size dari 33 perusahaan pada Subsektor Wholesale tahun 2017 dan 2018.

Tabel 3

Common size Laporan Posisi Keuangan Subsektor Wholesale

\begin{tabular}{|c|c|c|c|}
\hline \multirow{2}{*}{ Nama Akun } & \multicolumn{2}{|c|}{ Tahun } & \multirow{2}{*}{ Naik/Turun } \\
\hline & 2018 & 2017 & \\
\hline \multicolumn{4}{|l|}{ Aset } \\
\hline \multicolumn{4}{|l|}{ Aset lancar } \\
\hline Kas dan setara kas & 11,47 & 16,22 & $(4,75)$ \\
\hline Piutang usaha pihak ketiga & 15,24 & 16,69 & $(1,45)$ \\
\hline Piutang usaha pihak berelasi & 0,19 & 0,46 & $(0,27)$ \\
\hline Piutang lainnya & 5,32 & 5,69 & $(0,37)$ \\
\hline Persediaan lancar & 14,78 & 13,85 & 0,93 \\
\hline Biaya dibayar dimuka lancar & 0,83 & 0,83 & 0,01 \\
\hline Uang muka lancar & 0,83 & 1,02 & $(0,19)$ \\
\hline Pajak dibayar dimuka lancar & 1,37 & 1,07 & 0,31 \\
\hline Aset lancar lainnya & 4,13 & 3,52 & 0,61 \\
\hline Jumlah aset lancar & 54,13 & 59,29 & $(5,16)$ \\
\hline \multicolumn{4}{|l|}{ Aset tidak lancar } \\
\hline Aset pajak tangguhan & 1,36 & 1,74 & $(0,38)$ \\
\hline Aset tetap & 22,12 & 22,82 & $(0,70)$ \\
\hline Aset tidak lancar lainnya & 22,34 & 16,08 & 6,27 \\
\hline Jumlah aset tidak lancar & 45,83 & 40,65 & 5,17 \\
\hline Jumlah aset & 100,00 & 100,00 & $\mathbf{0 , 0 0}$ \\
\hline \multicolumn{4}{|l|}{ Liabilitas dan ekuitas } \\
\hline \multicolumn{4}{|l|}{ Liabilitas } \\
\hline \multicolumn{4}{|l|}{ Liabilitas jangka pendek } \\
\hline Pinjaman jangka pendek & 7,40 & 4,68 & 2,72 \\
\hline Utang usaha pihak ketiga & 21,28 & 18,64 & 2,63 \\
\hline Utang usaha pihak berelasi & 2,48 & 2,65 & $(0,17)$ \\
\hline Utang lainnya & 1,73 & 1,80 & $(0,07)$ \\
\hline Beban akrual jangka pendek & 2,27 & 2,01 & 0,26 \\
\hline Utang pajak & 2,10 & 1,15 & 0,95 \\
\hline Liabilitas jangka pendek lainnya & 4,62 & 6,84 & $(2,22)$ \\
\hline Jumlah liabilitas jangka pendek & 41,87 & 37,82 & 4,05 \\
\hline \multicolumn{4}{|l|}{ Liabilitas jangka panjang } \\
\hline Liabilitas jangka panjang atas utang bank & 6,20 & 7,90 & $(1,69)$ \\
\hline Kewajiban imbalan pasca kerja jangka panjang & 1,51 & 1,90 & $(0,39)$ \\
\hline Liabilitas jangka panjang lainnya & 4,62 & 3,78 & 0,84 \\
\hline Jumlah liabilitas jangka panjang & 12,33 & 13,57 & $(1,25)$ \\
\hline Jumlah liabilitas & 54,20 & 51,39 & 2,81 \\
\hline
\end{tabular}




\section{Ekuitas \\ Ekuitas yang diatribusikan kepada pemilik entitas induk}

Saham biasa

$5,26 \quad 6,53$

Tambahan modal disetor

8,39

10,12

Komponen ekuitas lainnya

$2,06 \quad 1,80$

Saldo laba yang telah ditentukan penggunaannya

0,26

0,32

Saldo laba yang belum ditentukan penggunaannya

$27,15 \quad 26,97$

Jumlah ekuitas yang diatribusikan kepada pemilik entitas induk

$42,84 \quad 45,35$

Kepentingan non-pengendali

Sumber: Data diolah (2020)

Aset lancar pada laporan posisi keuangan mencakup kas atau setara kas, piutang, persediaan, biaya dibayar di muka, uang muka, pajak dibayar di muka, dan aset lancar lainnya, yang diharapkan mampu direalisir dalam jangka waktu satu tahun. Persentase aset lancar dari tahun 2017 hingga tahun 2018 mengalami penurunan sebesar $5,16 \%$. Penurunan aset lancar ini disebabkan oleh menurunnya kas dan setara kas yang cukup tinggi yaitu sebesar $4,75 \%$. Penurunan pada pos aset lancar juga disebabkan oleh menurunnya piutang usaha pihak ketiga mengalami penurunan sebesar $1,45 \%$ dari tahun sebelumnya. Penurunan lainnya oleh menurunnya piutang usaha pihak berelasi, piutang lainnya, dan uang muka lancar. Aset lancar yang cenderung turun mencerminkan adanya penurunan pada likuiditas perusahaan (Djarwanto, 2004).

Aset tidak lancar merupakan kekayaan perusahaan yang memiliki wujud dan bersifat relatif permanen. Pada tahun 2017 persentase aset tidak lancar perusahaan sebesar 40,65\%, sedangkan pada tahun 2018 aset tidak lancar perusahaan sebesar $45,83 \%$. Hal tersebut menunjukkan adanya kenaikan aset tidak lancar yaitu sebesar 5,7\%. Kenaikan tersebut disebabkan oleh peningkatan aset tidak lancar lainnya yaitu sebesar 6,27\%. Aset tidak lancar perusahaan yang cenderung naik mencerminkan bahwa perusahaan mampu membiayai operasi perusahaan yang berasal dari modal sendiri dan penjualan (Djarwanto, 2004). Secara keseluruhan total aset mengalami kenaikan sebesar $21 \%$ atau senilai Rp45.284.544.611.771 dari total aset tahun sebelumnya.

Liabilitas jangka pendek merupakan kewajiban yang harus dipenuhi oleh perusahaan kepada pihak lain dalam jangka waktu satu tahun. Kondisi liabilitas jangka pendek perusahaan Sektor Wholesale pada 
tahun 2017 menunjukan persentase sebesar 37,82\%. Pada tahun 2018 persentase liabilitas jangka pendek meningkat menjadi $41,87 \%$ atau meningkat sebesar $4.05 \%$. Peningkatan tersebut disebabkan oleh meningkatnya pinjaman jangka pendek sebesar $2,72 \%$ serta utang usaha pihak ketiga yang mengalami kenaikan sebesar 2,63\%. Liabilitas jangka pendek yang menurun mencerminkan kondisi keuangan perusahaan untuk membayar utang dalam tempo yang telah ditentukan tidak dapat dibayarkan tepat waktu (Djarwanto, 2004).

$$
\text { Liabilitas jangka panjang }
$$
perusahaan mengalami penurunan dari tahun 2017 sebesar 13,57\% menjadi $12,33 \%$ pada tahun 2018. Penurunan tersebut terhitung sebesar $1,25 \%$ dari tahun sebelumnya. Penurunan tersebut disebabkan oleh menurunnya pos liabilitas jangka panjang atas utang bank sebesar 1,69\% dan kewajiban imbalan pasca kerja yang juga menurun sebesar $0,39 \%$. Liabilitas jangka panjang yang menurun mencerminkan bahwa perusahaan cukup baik dalam mengelola utang yang dimiliki.
Pada tahun 2017 persentase ekuitas perusahaan sebesar 48,61\%. Pada tahun 2018 mengalami penurunan menjadi $45,80 \%$. Penurunan tersebut terhitung sebesar $2,81 \%$ dari ekuitas tahun sebelumnya. Dilihat dari rata-rata jumlah ekuitas tahun 2017 dan 2018 persentase ekuitas perusahaan sebesar 47,20\%. Hal tersebut dinilai kurang baik karena menunjukkan rata-rata utang perusahaan berkontribusi lebih besar terhadap aset yakni sebesar 52,80\%.

\section{Analisis Common Size Laporan Laba Rugi}

Laporan laba rugi menampilkan hasil bersih dari operasi perusahaan. Sebagian besar kinerja perusahaan dinilai dari laba rugi. Oleh karena itu, laporan laba rugi merupakan salah satu komponen yang penting bagi perusahaan. Tabel 4 menyajikan laporan laba rugi dalam bentuk common size untuk 33 perusahaan pada Subsektor Wholesale periode tahun 2017 dan

2018. 
Tabel 4 Common size Laporan Laba Rugi Subsektor Wholesale

\begin{tabular}{|c|c|c|c|}
\hline \multirow{2}{*}{ Nama Akun } & \multicolumn{2}{|l|}{ Tahun } & \multirow{2}{*}{ Naik/Turun } \\
\hline & 2018 & 2017 & \\
\hline Penjualan dan pendapatan usaha & 100,00 & 100,00 & 0,00 \\
\hline Beban pokok penjualan dan pendapatan & $(84,28)$ & $(85,34)$ & 1,06 \\
\hline Jumlah laba bruto & 15,72 & 14,66 & 1,06 \\
\hline Beban Usaha & $(6,28)$ & $(7,03)$ & 0,75 \\
\hline Beban (pendapatan) lain-lain & $(1,19)$ & $(1,59)$ & 0,41 \\
\hline $\begin{array}{l}\text { Jumlah laba (rugi) sebelum pajak } \\
\text { penghasilan }\end{array}$ & 8,25 & 6,04 & 2,21 \\
\hline Beban (pendapatan) Pajak Penghasilan & $(2,48)$ & $(2,12)$ & $(0,36)$ \\
\hline Jumlah laba (rugi) & 7,80 & 4,23 & 3,57 \\
\hline $\begin{array}{l}\text { Jumlah pendapatan (beban) komprehensif, } \\
\text { setelah pajak }\end{array}$ & 0,61 & $(0,11)$ & 0,72 \\
\hline Jumlah laba (rugi) komprehensif & 8,41 & 4,13 & 4,29 \\
\hline Laba (rugi) yang dapat diatribusikan & & & \\
\hline $\begin{array}{l}\text { Laba (rugi) yang dapat diatribusikan ke } \\
\text { entitas induk }\end{array}$ & 7,82 & 4,24 & 3,58 \\
\hline $\begin{array}{l}\text { Laba (rugi) yang dapat diatribusikan ke } \\
\text { kepentingan non-pengendali }\end{array}$ & $(0,02)$ & $(0,00)$ & $(0,01)$ \\
\hline $\begin{array}{l}\text { Laba rugi komprehensif yang dapat } \\
\text { diatribusikan }\end{array}$ & & & \\
\hline $\begin{array}{l}\text { Laba (rugi) komprehensif yang dapat } \\
\text { diatribusikan ke entitas induk }\end{array}$ & 8,38 & 4,13 & 4,25 \\
\hline $\begin{array}{l}\text { Laba (rugi) komprehensif yang dapat } \\
\begin{array}{l}\text { diatribusikan } \\
\text { pengendali }\end{array}\end{array}$ & 0,04 & $(0,00)$ & 0,04 \\
\hline
\end{tabular}

Sumber: Data diolah (2020)

Item pertama dari laporan laba rugi yang dianalisis dalam laporan ini adalah penjualan bersih. Penjualan bersih mengalami kenaikan dari tahun 2017 yang senilai Rp186.601.879.181.339 menjadi senilai Rp225.657.912.619.899 pada tahun 2018. Kenaikan tersebut terhitung sebesar $17 \%$ atau senilai Rp39.056.033.438.560 dari total penjualan tahun sebelumnya.

Beban pokok penjualan adalah harga pokok barang dagangan yang dibeli yang kemudian berhasil dijual selama suatu periode akuntansi. Persentase beban pokok penjualan yang pada tahun 2017 sebesar $85,34 \%$ dari penjualan mengalami penurunan tingkat menjadi sebesar $84,28 \%$ pada tahun 2018. Sehingga persentase beban pokok penjualan terhitung menurun sebesar $1,06 \%$ yang menyebabkan laba bruto juga mengalami peningkatan sebesar $1,06 \%$ dari tahun sebelumnya. Beban pokok penjualan yang turun mencerminkan kinerja perusahaan yang baik karena mampu mengendalikan beban pokok 
penjualan sehingga mampu meningkatkan laba kotor dari penjualan yang terjadi (Djarwanto, 2004).

Pada tahun 2018 perusahaaan menekan beban-beban yang dikeluarkan seperti beban penjualan serta beban umum dan administrasi yang terlihat dari menurunnya beban usaha sebesar $0,75 \%$. Beban lainnya juga terhitung menurun sebesar $0,41 \%$ dari tahun sebelumnya. Beban usaha yang mengalami penurunan mencerminkan perusahaan baik dalam menekan beban-bebannya sehinga pendapatan perusahaan mengalami peningkatan. Karena beban-beban yang cenderung menurun, jumlah laba sebelum pajak penghasilan mengalami peningkatan sebesar 2,21\%. Hal tersebut menyebabkan beban pajak penghasilan mengalami kenaikan sebesar 0,36\% dari beban pajak penghasilan tahun sebelumnya.

Laba bersih adalah laba yang diiperoleh oleh perusahan setelah penjualan bersih perusahaan dikurangi oleh beban pokok penjualan, beban usaha, dan pajak. Perolehan laba bersih perusahaan Subsektor Wholesale mengalami kenaikan yang cukup signifikan sebesar $3,57 \%$ atau senilai Rp9.710.111.733.366 dari perolehan tahun 2017 yang sebesar 4,23\% atau senilai $\mathrm{Rp}$ 7.901.501.909.560 menjadi $7,80 \%$ atau senilai Rp 17.611.613.642.926 pada tahun 2018. Dapat disimpulkan bahwa kinerja perusahaan pada tahun 2018 cukup baik karena mampu meningkatkan perolehan laba dari tahun sebelumnya.

\section{Analisis Rasio Likuiditas}

Berikut ini disajikan hasil perhitungan rasio likuiditas perusahaan pada Subsektor Wholesale di BEI tahun 2017 dan 2018:

Tabel 5

Rasio Likuiditas Subsektor Wholesale

\begin{tabular}{lrr}
\hline $\begin{array}{c}\text { Rasio } \\
\text { Likuiditas }\end{array}$ & \multicolumn{1}{c}{$\mathbf{2 0 1 8}$} & \multicolumn{1}{c}{$\mathbf{2 0 1 7}$} \\
\hline Current ratio & $129,27 \%$ & $156,78 \%$ \\
Quick ratio & $93,98 \%$ & $120,15 \%$ \\
Cash ratio & $27,39 \%$ & $42,89 \%$ \\
\hline \multicolumn{3}{l}{ Sumber: Data diolah $(2020)$}
\end{tabular}

Dari data di atas dapat dilihat hasil dari perhitungan current ratio pada Subsektor Wholesale tahun 2017 menunjukkan bahwa setiap 1 utang lancar dapat dijamin oleh aset lancar sebesar 156,78\%. Pada tahun 2018, rasio tersebut mengalami penurunan menjadi $129,27 \%$. Penurunan yang terhitung sebesar 27,50\% tersebut disebabkan karena menurunnya jumlah aset lancar dan naiknya utang jangka pendek pada tahun 2018. Dapat disimpulkan bahwa current ratio pada Subsektor Wholesale tahun 2018 kurang baik karena nilainya tidak mencapai $200 \%$ yang berarti aset lancar perusahaan tidak maksimal bisa menjamin utang lancar yang segera jatuh tempo (Kasmir, 2017). 
Hasil perhitungan rasio cepat menunjukkan bahwa hasil perhitungan quick ratio pada tahun 2017 sebesar 120,15\%. Pada tahun 2018 perusahaan mengalami penurunan rasio cepat sebesar $26,18 \%$ menjadi 93,98\%. Dapat disimpulkan bahwa kondisi perusahaan kurang baik dilihat dari hasil rasio cepatnya yang masih di bawah standar industri yaitu sebesar 150\% (Kasmir, 2017).

Pada tabel 5, rasio kas Subsektor Wholesale pada tahun 2017 sebesar 42,89\% dan pada tahun berikutnya yaitu tahun 2018 mengalami penurunan sebesar 15,49\% menjadi 27,39\%. Bila dilihat dari perhitungan tersebut dapat disimpulkan bahwa rasio kas kurang baik karena di bawah standar industri yaitu 50\% (Kasmir, 2017). Hal tersebut mengindikasikan bahwa kas yang dimiliki perusahaan tidak menjamin liabilitas jangka pendeknya.

\section{Analisis Rasio Solvabilitas}

Berikut ini disajikan hasil perhitungan rasio solvabilitas perusahaan pada Subsektor Wholesale di BEI tahun 2017 dan 2018:

Tabel 6 Rasio Solvabilitas Subsektor Wholesale

\begin{tabular}{crr}
\hline Rasio Solvabilitas & $\mathbf{2 0 1 8}$ & \multicolumn{1}{c}{$\mathbf{2 0 1 7}$} \\
\hline Debt to Asset Ratio & $54,20 \%$ & $51,39 \%$ \\
Debt to Equity Ratio & $118,34 \%$ & $105,73 \%$
\end{tabular}

Sumber: Data diolah (2020)
Pada tabel 6 dapat dilihat bahwa hasil perhitungan debt to asset ratio pada Subsektor Wholesale tahun 2017 sebesar $51,39 \%$ dan meningkat pada tahun 2018 menjadi $54,20 \%$. Peningkatan yang terjadi yaitu sebesar 2,81\% dari tahun sebelumnya. Hasil rasio tersebut berada di atas standar industri yaitu $35 \%$ yang menunjukkan bahwa aset lebih banyak dibiayai oleh liabilitas. Semakin tinggi hasil perhitungan debt to asset ratio maka semakin tidak baik karena pendanaan oleh liabilitas lebih banyak. Hal tersebut akan menyulitkan perusahaan jika ingin memperoleh tambahan pinjaman karena dikhawatirkan perusahaan tidak mampu memenuhi liabilitasnya dengan aset dimiliki (Kasmir, 2017). Walau liabilitas selain dapat berdampak buruk juga dapat berdampak baik, tergantung bagaimana kemampuan perusahaan dalam mengelolanya (Zulkarnain et al., 2020).

Hasil perhitungan debt to equity ratio pada tahun 2017 sebesar 105,73\% dan meningkat sebanyak $12,61 \%$ pada tahun 2018 menjadi 118,34\%. Hal ini disebabkan oleh meningkatnya liabilitas dan menurunnya ekuitas pada tahun 2018. Debt to equity ratio dikatakan kurang baik karena berada di atas standar industri yaitu sebesar $90 \%$ yang berarti tingkat risikonya lebih tinggi (Kasmir, 2017). Debt to asset ratio yang tinggi dalam beberapa kasus 
dapat menurunkan nilai perusahaan

(Zulkarnain \& Farida, 2018).

\section{Analisis Rasio Aktivitas}

Berikut ini disajikan hasil perhitungan rasio aktivitas pada Subsektor Wholesale di BEI tahun 2017 dan 2018:

Tabel 7 Rasio Aktivitas Subsektor

\section{Wholesale}

\begin{tabular}{lrc}
\hline \multicolumn{1}{c}{ Rasio Aktivitas } & $\mathbf{2 0 1 8}$ & $\mathbf{2 0 1 7}$ \\
\hline Total Asset Turnover & 1,05 & 1,10 \\
Inventory turnover & 7,12 & 7,96 \\
\hline
\end{tabular}

Sumber: Data diolah (2020)

Pada tabel 6 dapat dilihat bahwa hasil perhitungan total asset turnover pada Subsektor Wholesale tahun 2017 sebanyak 1,10 kali dan menurun pada tahun 2018 menjadi 1,05 kali. Hasil perhitungan tersebut menunjukkan bahwa perputaran aset belum maksimal karena masih berada di bawah standar industri yaitu 2 kali (Kasmir, 2017).

$$
\text { Hasil perhitungan inventory }
$$
turnover ratio pada tahun 2017 sebanyak 7,12 kali dan menurun menjadi 7,12 kali pada tahun 2018. Hal ini menunjukkan bahwa perusahaan belum bekerja secara efektif karena hasil perhitungan perputaran persediaan masih di bawah standar industri yaitu 20 kali (Kasmir, 2017).

\section{Analisis Rasio Profitabilitas}

Berikut ini disajikan hasil perhitungan rasio profitabilitas pada
Subsektor Wholesale di BEI tahun 2017 dan 2018:

Tabel 8 Rasio Profitabilitas Subsektor Wholesale

\begin{tabular}{lcc}
\hline \multicolumn{1}{c}{$\begin{array}{c}\text { Rasio } \\
\text { Profitabilitas }\end{array}$} & $\mathbf{2 0 1 8}$ & $\mathbf{2 0 1 7}$ \\
\hline $\begin{array}{l}\text { Gross profit } \\
\text { margin (GPM) }\end{array}$ & $15,72 \%$ & $14,66 \%$ \\
$\begin{array}{l}\text { Net profit margin } \\
\text { (NPM) }\end{array}$ & $7,80 \%$ & $4,23 \%$ \\
$\begin{array}{l}\text { Return on Equity } \\
\text { (ROE) }\end{array}$ & $17,93 \%$ & $9,61 \%$ \\
\hline Sumber: Data diolah $(2020)$ &
\end{tabular}

Dari data di atas dapat dilihat hasil dari perhitungan GPM pada Subsektor Wholesale tahun 2017 sebesar 14,66\%. Pada tahun 2018 rasio tersebut meningkat sebesar $1,06 \%$ menjadi $15,72 \%$. Perusahaan sudah menunjukkan kinerja yang baik dengan meningkatnya penjualan dan menurunnya beban pokok penjualan sehingga dapat meningkatkan laba kotor. Namun hasil rasio tersebut masih berada di bawah standar industri yaitu 30\% (Kasmir, 2017).

Hasil dari perhitungan NPM pada Subsektor Wholesale tahun 2017 sebesar 4,23\%. Pada tahun 2018 rasio tersebut mengalami peningkatan yang cukup signifikan yaitu sebesar $3,57 \%$ menjadi $7,80 \%$. Perusahaan sudah menunjukkan kinerja yang baik dengan meningkatnya rasio ini yang berarti laba bersih perusahaan mengalami peningkatan. Namun hasil rasio tersebut masih berada di 
bawah standar industri yaitu 20\% (Kasmir, 2017).

Pada tabel 8, ROE Subsektor Wholesale pada tahun 2017 sebesar 9,61\% dan pada tahun berikutnya yaitu tahun 2018 mengalami peningkatan yang signifikan sebesar $8,32 \%$ menjadi $17,93 \%$. Dapat disimpulkan bahwa perusahaan menampilkan kinerja yang baik karena dapat meningkatkan ROE dari tahun sebelumnya. Namun, hasil rasio tersebut masih berada di bawah standar industri yaitu 40\% (Kasmir, 2017).

\section{SIMPULAN}

Berdasarkan analisis common size dan rasio keuangan yang telah dilakukan pada laporan keuangan Subsektor Wholesale tahun 2017 dan 2018 dapat disimpulkan bahwa:

1. Pada analisis common size laporan posisi keuangan Subsektor Wholesale tahun 2017 dan 2018 secara keseluruhan total aset pada tahun 2018 mengalami kenaikan sebesar $21 \%$ dari tahun sebelumnya. Meskipun aset lancar menurun, aset tidak lancar menunjukkan adanya kenaikan. Untuk sisi liabilitas dan ekuitas, liabilitas jangka pendek meningkat. Sedangkan liabilitas jangka panjang dan ekuitas menurun.
2. Pada analisis common size laporan laba rugi Subsektor Wholesale tahun 2017 dan 2018, penjualan pada tahun 2018 meningkat $17 \%$ dari tahun sebelumnya. Beban pokok penjualan dan beban usaha juga mengalami penurunan sehingga laba bersih yang didapatkan meningkat dari tahun sebelumnya.

3. Rasio likuiditas yang dihitung dengan current ratio, quick ratio, dan cash ratio pada Subsektor Wholesale tahun 2017 dan 2018 dalam keadaan kurang baik karena hasil dari ketiga rasio tersebut mengalami penurunan dan kurang dari standar rata-rata industri. Hal tersebut disebabkan oleh menurunnya jumlah aset lancar dan naiknya utang jangka pendek.

4. Rasio solvabilitas yang dihitung dengan debt to asset ratio dan debt to equity ratio pada Subsektor Wholesale tahun 2017 dan 2018 dalam keadaan kurang baik karena hasil dari ketiga rasio tersebut lebih dari standar ratarata industri dan mengalami peningkatan. Hal tersebut disebabkan oleh naiknya utang jangka pendek, sedangkan aset lancar dan ekuitas menurun.

5. Rasio aktivitas yang dihitung dengan total assets turnover dan inventory turnover pada Subsektor Wholesale 
tahun 2017 dan 2018 dalam keadaan kurang baik karena hasil dari ketiga rasio tersebut kurang dari standar ratarata industri dan mengalami penurunan. Hal ini menunjukkan bahwa perusahaan belum mampu bekerja secara maksimal dalam memanfaatkan sumber daya pada kegiatan operasionalnya.

6. Rasio profitabilitas yang dihitung dengan gross profit margin, net profit margin, dan return of equity mengalami peningkatan pada masingmasing rasio tersebut. Hal ini menunjukkan bahwa perusahaan bekerja dengan baik. Namun, hasil rasio tersebut masih berada di bawah standar industri.

\section{DAFTAR PUSTAKA}

Djarwanto. (2004). Pokok-Pokok Analisis Laporan Keuangan. BPFE.

Fahmi, I. (2015). Analisis Laporan Keuangan. Alfabeta.

Firdausia, Y. K., \& Ariyanto, B. (2018). Analisis Pengaruh Kinerja Keuangan Terhadap Harga Saham Pada Perusahaan Wholesale and Retail Trade Yang Terdaftar di Bursa Efek Indonesia (BEI) Tahun 2011-2016. Majalah Ekonomi, 23(2), 305-314.

Grisely, G., Basri, Y. M., \& Silfi, A. (2015). Analisis Pengaruh Rasio Keuangan terhadap Perubahan Laba pada Perusahaan Wholesale And
Retail Trade yang Terdaftar di Bursa Efek Indonesia (Periode 2009-2012). Jom FEKON, 2(1), 1-15.

Hery. (2015). Analisis Laporan Keuangan Pendekatan Rasio Keuangan. CAPS.

Jumingan. (2017). Analisis Laporan Keuangan. Bumi Aksara.

Kasmir. (2017). Analisis Laporan Keuangan. PT Raja Grafindo Persada.

Munawir, S. (2014). Analisa Laporan Keuangan. Liberty.

Olivia, G., \& Tendi. (2019). Pertumbuhan Sektor Perdagangan dan Infokom Melaju Sepanjang Kuartal I-2019. Nasional.Kontan.Co.Id. https://nasional.kontan.co.id/news/pert umbuhan-sektor-perdagangan-daninfokom-melaju-sepanjang-kuartal-i2019

Purwantini, H. (2017). Peran Kinerja Keuangan Terhadap Harga Saham Pada Perusahaan Wholesale and Retail Trade Terdaftar di BEI. Jurnal Akuntansi Jayanegara, 9(2), 136-149.

Zulkarnain, Z., \& Farida, R. (2018). Peran Profitability dan Capital Structure dalam Memengaruhi Firm Value. Cakrawala, 1(2), 89-99.

Zulkarnain, Z., Syahara, R., \& Novitasari, Y. (2020). Pengaruh ROA dan DER Terhadap Stock Price pada Perusahaan Makanan dan Minuman yang Terdaftar di BEI Periode 2013-2017. Cakrawala, 3(1), 22-32. 